соціалізація, завдяки якій дитина та майбутні батьки реконструюють образ навколишньої дійсності та вибудовують систему коннотаційних значень, також пов'язаних із вагітністю та потенційним чи справжнім материнством та батьківством. Прийняття материнської ролі повинно відбуватися на декількох рівнях одночасно: свідомому та несвідомому, соціальному, інтелектуальному, фізичному та емоційному. Саме таке поєднання дає позитивну перспективу благополучного перебігу вагітності, народженню та виховання здорової особистості.

\title{
Література:
}

1. Гроф С. За пределами мозга: Рождение, смерть и трансценденция в психотерапии. - 3-е изд. - М.: Ин-т Трансперсональной Психологии, Изд-во Ин-та Психотерапии, 2000

2. Даниленко Н.В. Методи дослідження готовності до материнства. Н.В.Даниленко // Вi- сник ХНПУ ім. Г.С.Сковороди. Психологія. Харків, 2005. - Вип. 15

3. Филиппова Г.Г. Материнство и основные аспекты его исследования в психологии / Г.Г Филиппова // Вопросы психологии. С. 4.

4. Яремчук Н.В. Психологічні особливості готовності молодої жінки до майбутнього материнства / Н.В.Яремчук // Вісник піс-лядипломної освіти: зб. наук. пр. / [редкол. В.В.Олійник (голов. ред.) та ін.]. - К., 2008. -Вип. 7.

DOI https://doi.org/10.30525/978-9934-26-114-5-6

\section{PROFESSIONAL RESPONSIBILITY OF THE FUTURE TEACHERS: THE ESSENCE AND PROBLEM OF FORMATION}

\author{
Meshko H. M. \\ Dr. of Pedagogy, Professor,
} Head of the Department of Pedagogy and Education Management Ternopil Volodymyr Hnatyuk National Pedagogical University

Meshko O. I.

Ph.D. of Psychology, Associate Professor, Associate Professor of the Department of Psychology Ternopil Volodymyr Hnatyuk National Pedagogical University

Ternopil, Ukraine

Today the school needs a new generation teacher with a formed professional and pedagogical position, competent, reliable, and responsible. 
Teacher's professional responsibility is the key to successful pedagogical activity, guarantees a positive result, and reduces the risk of professional errors and professional omissions. Professional responsibility is an integral quality of a teacher's personality, which presupposes careful (honest) performance of professional duties, guaranteeing the preservation of the proper level and quality of pedagogical activity, despite unforeseen difficulties [5, p. 103]. Attitude to professional responsibilities depends on the vital and professional position of the teacher's personality. At the responsible attitude to the professional duties teachers show the maximum activity and productivity, at indifferent - formally carry out the requirements concerning them, at the negative attitude try to make as little as possible, do not provide the quality of work and its result. Therefore, the formation of professional responsibility is an objective requirement of modern society and an important task of pedagogical education.

Professional responsibility, in the scientific literature, is defined as a property of the individual that reflects the attitude of the subject to its content and results, other subjects, and himself in the process of work. The nature of this attitude is due to the need for clear and complete implementation (compliance) in the professional activities of the proposed requirements and rules, as well as the willingness to report on the results of their own activities [9, p. 395].

Noteworthy is the approach of V. Sushchenko, who interprets the professional responsibility of a worker as the ability to report to himself and others, society, the state about the results of their professional activities and receive based on such reporting from themselves and others positive or negative assessments (sanctions) of their professional activities [8, p. 6]

Responsibility is based on main psychological formations - selfawareness of the individual and its components such as self-esteem, selfconcept of personality, also relevant psychological mechanisms (selfregulation and reflection). The internal instance of responsibility is conscience [6].

Professional values are the internal guideline that guides the professional actions and deeds of the teacher and determines the level of his responsibility. In the scientific literature $[4 ; 8]$ professional values are defined as an integrative personal education that encompasses the goals, motives, ideals, attitudes, and other worldview characteristics of the individual, which are the basis of its value orientations and meanings. Professional values accumulate in the professional position of the teacher as a system of his effective attitudes. Professional values determine the principles of behaviour of the teacher; regulate his motivational sphere and activities. For a teacher, professional values are a criterion for assessing the 
pedagogical reality, behaviour, and actions of others and himself. The formation of professional values provides a responsible attitude to professional activity, promotes integration and expression in the minds of students' axiological model of future professional activity.

For our study, the thought of S. Buksha is relevant, who believes that professional responsibility integrates the moral and volitional, and professional qualities of future teachers in the new formation, which is purposefully formed and developed in special training [2, p. 49]. Therefore, an important issue is to find ways to maintain the professional responsibility of future teachers at the stage of professional training in higher education.

The integrated course «Pedagogy» is focused primarily on the formation of professional responsibility of future teachers, which includes the following content modules: «Introduction to the teaching profession»; «School pedagogy»; «Fundamentals of inclusive education»; «History of pedagogy»; propaedeutic practice.

The use of diagnostic techniques, tests for self-understanding during the study of the content module «Introduction to the teaching profession» contributes to the formation of adequate self-esteem, self-concept, the subjective position of the student, which is the basis of his professional responsibility. The professional responsibility formation of the future teachers is facilitated by the implementation of creative tasks: 1) to prepare an essay on one of the proposed topics: «Mission of the teacher of the third millennium»; «My life and professional credo»; «Professional values of modern teachers». «Professional irresponsibility and professional hyper responsibility: two sides of the same problem», etc.; 2) to take the "Oath of the teacher»; 3) to compile a «Code of Professional Activity and Responsibility», etc. It is important for us that the students in the future action based on the conscious, motivated implementation of the deontological code of pedagogical activity.

Analysing the professional situations, solving pedagogical problems, micro-teaching, we use such methods of acmeological influence as the method of «strengthening the dominant motives», the method of «discrediting», the method of «meaning formation», the method of «generating motives», which were not previously in the motivational hierarchy of students. These are «subtle» methods of purposeful psychological influence, borrowed by us from acmeology [1;3], which allow us to manage the behaviour and activities of future teachers for professional purposes, contribute to the formation of a responsible attitude to professional activities, and their results, to themselves and other actors in the educational process. These methods are closely «intertwined» and successfully combined with elements of psychological and pedagogical training (discussions, roleplaying situations, the use of parables, analysis of psycho-drawings, etc.). 
The professional and pedagogical position of the teacher, the value orientations of the student group and the whole system of attitudes of future teachers to the future profession and pedagogical reality are reflected in the process of forming professional responsibility. The pedagogical practice, the involvement of students in research, community, and volunteer activities are of importance in this aspect.

Therefore, we see the prospects for further research in the justification, development, and implementation of a system of professional responsibility of future teachers at the stage of training.

\section{References:}

1. Акмеология: учебник / под общ. ред. А.А. Деркача. М. : Изд-во РАГС, 2002. $681 \mathrm{c}$.

2. Букша С.Б. Формирование профессиональной ответственности учителей основ здоровья. Профильная школа. 2014. № 1. С. 48-54.

3. Гладкова В.М., Пожарський С.Д. Основи акмеології: підручник. Л. : Новий Світ-2000, 2007. 320 с.

4. Максимчук Н.П. Професійні ціннісні орієнтації майбутнього вчителя в системі особистих ціннісних орієнтацій. Проблеми сучасної психології. Збірник наукових праць КПНУ імені Івана Огієнка, Інституту психології імені Г.С. Костюка НАПН України, 2011. Випуск 12. С. 635-642.

5. Мешко Г.М., Мешко О.І. Формування професійної відповідальності майбутніх учителів як предмет наукового аналізу. Професійна компетентність учителя нової украӥнської школи: формування, розвиток та удосконалення: матеріали Міжнародної науково-практичної Інтернет-конференції (Тернопіль, 22 травня 2020 р.) / за ред. В.М. Чайки. Тернопіль : ТНПУ ім. В. Гнатюка, 2020. С. 102-104.

6. Савчин М.В. Психологія відповідальної поведінки: монографія. Івано-Франківськ : Місто НВ, 2008. 280 с.

7. Сластенин В.А., Чижакова Г.И. Введение в педагогическую аксиологию: учеб. пособие. М. : Изд. центр «Академия», 2003. 192 с.

8. Сущенко В.М. Професійна відповідальність юриста: деонтологічні та правові проблеми. Наукові записки НаУКМА. Том 20: Юридичні науки. 2002. C. 4-7. http://ekmair.ukma.edu.ua/handle/ $123456789 / 13573$

9. Ткачов А.В. Проблема професійної відповідальності особистості в психології. Проблеми екстремальної та кризової психології: зб. наук. праць / гол. ред. Л.А. Перелигіна. Харків: УЦЗУ, 2010. Вип. 8. С. $395-400$. 